\title{
HEALTHCARE AS A TASK OF LOCAL GOVERNMENT IN POLAND
}

\section{DOROTA KORENIK}

\begin{tabular}{|c|c|}
\hline & $\begin{array}{l}\text { Wroctaw University of Economics, POLAND } \\
\text { e-mail: dorota.korenik@ue.wroc.pl }\end{array}$ \\
\hline $\begin{array}{l}\text { RECEIVED } \\
\text { ACCEPTED }\end{array}$ & $\begin{array}{l}16 \text { January } 2017 \\
10 \text { February } 2017\end{array}$ \\
\hline $\begin{array}{l}\text { JEL } \\
\text { CLASSIFICATION }\end{array}$ & L75, 118 \\
\hline KEYWORDS & benchmarking of hospitals, state-local governance \\
\hline ABSTRACT & $\begin{array}{l}\text { The subject of this article is benchmarking existing hospitals in order to cover the healthcare demand of } \\
\text { Polish local communities. Duly performed ownership supervision should include an impartial evaluation of } \\
\text { the head managers and their relevant motivation to improve quality while maintaining acceptable profitability. } \\
\text { Lack of practical tools, such as best practice guidelines for local governments, and of tools which would help } \\
\text { to implement them, prevents from keeping relevant supervision over dependent hospitals. The aim of this } \\
\text { study was to introduce the concept of a practical benchmarking instrument relevant to actual issues that local } \\
\text { government meets when supervising their hospitals. The concept of benchmarking is approached from various } \\
\text { perspectives: a way of learning from the best, an instrument which contributes to the management efficiency } \\
\text { improvement and a tool for monitoring results of the management of the hospital. }\end{array}$ \\
\hline
\end{tabular}

\section{Introduction}

Many years of autonomous operation of medical entities virtually eliminated those directors who disputed the need of management (not mere administrating) in decision-making process on strategic, tactical and operational level and in various areas of basic and auxiliary activity (Public..., 2000). Nevertheless, the lack of critical analysis 
and impartial assessment of processes in hospitals is still an issue and is manifestly contrary to the will of assessment of hospitals by various entities for various reasons.

Basic financial reports, strategic and operational plans, corrective plans or quality assessments are standard practices when it comes to evaluating management effectiveness in hospitals. However, without an evaluation of the quality and correctness of documents that presented, these practices provide no answer for the questions that refer to good management, such as:

- Does the hospital work well?

- Are its methods the best?

- Can the best be attained? What would the best be in this case?

- What does a "good" grade stand for in case of hospitals?

Such evaluation in case of Polish entities usually boils down to analysis of one or some of the following (Rój, Sobiech, 2006): bottom line, liabilities, including claimable ones, level of investments, bed occupancy, percentage of completion of the contract with National Healthcare Service (NFZ). Those indicators, and others related to productivity or effectiveness indicators, do not, however, answer the most important questions. It should be noted that an entity called the Quality Monitoring Center (Centrum Monitorowania Jakości), subject to the Ministry of Health but operating on commercial basis, does exist in Kraków. The organisation performs analyses of various productivity indicators for hospitals and creates their rankings based on their own internal database. It also offers courses in creating and promoting the so-called good practices in healthcare. There are also publications on measuring and evaluating hospital performance, increasing in numbers. Interesting research was initiated at the University of Szczecin in 2009. It was focused on creating the Hospital Evaluation Card to help in hospital management, (see Hass Symotiuk, 2011). They were also involved in other research on measuring and evaluating hospital performance in balanced evaluation cards. Some regional hospitals have also worked on measuring static economic effectiveness (see Nojszewska), and attempted to benchmark basing on chosen indicators of static economic effectiveness (see Porębski, 2016). These works enrich the knowledge on proper behaviour in healthcare institutions. Nevertheless, a research gap existed in the form of a lacking benchmarking tool that could be useful in complex hospital management, using benchmarking as an important method of management and ownership supervision.

At the same time, insufficient supervision over dependent hospitals due to lack of well-developed practical tools of work quality monitoring (efficiency in terms of praxeology) and economic efficiency (profitability) is still an issue for local governments. Good ownership supervision should be an aid in objective evaluation of management work and hospital's performance, and it should motivate management to improve the quality of work while keeping the profitability on acceptable level (a non-negative long term bottom line, with permissible short term negative in time investments in the hospital).

Dependent hospitals cannot be supervised properly due to lack of practical solutions such as best practice guidelines and tools to apply them. This raises further issues: risk of further waste of public resources in poorly managed hospitals, low economic efficiency of a hospital and its deterioration, reducing its ability to improve quality and, in case of permanent negative profit, raising the issue of covering the losses by local government or permanent shutdown. Thus, lack of an efficient, extensive control tool for quality and effectiveness, which would be available for permanent use, hinders solutions of such issues. 
Defining objective and comparable criteria of assessing hospitals as a sophisticated research instrument of comparison and proper orientation for long term activity becomes, therefore, urgently necessary.

Benchmarking seems to be a perfect tool for such purpose. It evaluates the work of management and compares it to the cases of other similar hospitals. Therefore, the founding bodies should seek to take advantage of that instrument in assessment of dependant medical entities.

\section{Meaning of henchmarking in hospitals}

Benchmarking helps to determine strengths and weaknesses of an entity in question in order to find best ways of improvement: procedures, processes, skills, organisational structures, and ways of running business. And this concerns medical entities (hospitals) as well.

Benchmarking, in case of medical institutions, can be understood as:

- an element of a specific form of management,

- a method of analysis and evaluation of part or whole of business achievements in comparison to other entities (specifically defined group of entities),

- an element of owner's supervision and management performance review,

- condition of availability of certain profits (like prestigious awards) or specific public funds in part of distributive activity of the government (public service contract),

- a subject of scientific research directed at finding best practices to apply in certain social-economic, political and legal circumstances.

\section{Benchmarking in management}

Benchmarking can be (but does not have to be) applied to various management methods such as management by objectives which is usually practiced in hospitals. It can be applied voluntarily, on directors' own initiative, or as a result of the actions of entities influencing their decisions, such as public players who cover costs of medical services or owners of the supervisory entity. It is the most important, however, for entities interested in quality management, as one of three management tools which are strictly interconnected with each other: 1) employees' duties, 2) benchmarking, 3) quality improvement process.

The benchmarking process should entail the procedures identified through the process of direct target achievement, in order to achieve indirect targets of benchmarking, among which are: increase of patient satisfaction (a common quality measure); competitive advantage (an economic indicator which refers to high quality of work in a certain aspect of medical activity); reorientation of focus (a common economic criterion, requiring resources of high quality); modification of previous practice in order to improve the quality of work; improvement of management skills including competences necessary to use adequate measurement instruments in management; overcoming the reluctance to ideas from outside (quality of human factor); acceleration of changes.

While benchmarking theory focuses on the issue of quality, it cannot deflate the financial side of management with benchmarking. Quality improvement and maintaining means costs, so, logically, one cannot ignore the financial question. Unless previous financial targets (including the financial balance of the organization) are of equivalent or higher priority than the quality targets, they have to be treated as "boundary criteria" in quality improvement process. Benchmarking should therefore cover the financial aspects of hospital's activity as well. 


\section{Benchmarking as a method of analysis and evaluation of the achievements of a medical institution}

Benchmarking can be used in case of any medical entity or its organisational unit, whether committed to leadership through quality or any other management strategy (such as management by objectives) and evaluated in comparison to others. Its management team can use benchmarking occasionally or regularly, on their own, on command of an owner wanting an additional reference plane for evaluation, for creation of integrated evaluation system for all dependent medical entities (manager performance evaluation), or else on command of public players, organs or agencies of ministry for the purpose of medical policy. Benchmarking can be applied to the whole organisation, to all or some areas of its activity or to specific functions (e.g. finance, controlling, production, supplies, etc.) and specific kinds of effects (e.g. financial effectiveness, medical market share in given area). All such indicators as processes and functions in the organisation, their effectiveness, services, staff and value perceived by clients (patients) can be compared. Various existing models, such as strategic achievements card or models elaborated for specific environmental conditions with hierarchical analysis of the problem may include instruments of benchmarking. Each instrument can be applied by a medical entity for the purposes of control and internal improvement of key business areas: patients, internal processes, development, finance (Table 1), especially as a measure and evaluation of achievements and as a comparison tool. Such tools can be helpful for external stakeholders as well.

Table 1. Analysis of medical entity's business areas as seen by internal and external stakeholders

\begin{tabular}{lll}
\hline \multicolumn{1}{c}{ Business area } & \multicolumn{1}{c}{ Management } & \multicolumn{1}{c}{$\begin{array}{c}\text { Other internal or External stakeholder } \\
\text { (healthcare policy) }\end{array}$} \\
\hline Patient & $\begin{array}{l}\text { Does the organization provide healthcare according to current } \\
\text { medical (strictly clinical area) and economic (cost effectiveness } \\
\text { of medical procedures) knowledge. }\end{array}$ & $\begin{array}{l}\text { Are social needs met, and to what extent. Is the continuity } \\
\text { and widespread access to healthcare as well as promotion } \\
\text { of health ensured. } \\
\text { Internal processes }\end{array}$ \\
& $\begin{array}{l}\text { Is the internal process of resources management rational } \\
\text { (and to what extent) in order to build a stable, long-term basis for } \\
\text { key activity, which is the area of patient care). Analysis } \\
\text { of condition and rate of use of healthcare resources (on country- }\end{array}$ & $\begin{array}{l}\text { The condition and rate of use of healthcare resources } \\
\text { and analysed (on country, regional and local level). }\end{array}$ \\
& $\begin{array}{l}\text { wide, regional and local level). } \\
\text { Human resources (potential, competence, expertise, } \\
\text { contentment) analysed in terms of organisation's development } \\
\text { goals such as implementing a new medical procedure, } \\
\text { development of management methods, development } \\
\text { of medical technologies in use. }\end{array}$ & $\begin{array}{l}\text { Future demand for clinical specialists, new medical } \\
\text { technology, new management methods (e.g. with public- } \\
\text { private partnership, outsourcing some auxiliary functions } \\
\text { etc.). }\end{array}$ \\
\hline Finance & $\begin{array}{l}\text { Analysis and evaluation of financial force of the organization } \\
\text { and financial management }\end{array}$ & $\begin{array}{l}\text { Analysis of costs of healthcare industry, allocation of public } \\
\text { funds to medical entities, rationality of their allocation. }\end{array}$ \\
\hline
\end{tabular}

Source: original research.

\section{Benchmarking of (non-medial) therapeutic activity}

There is general misconception that imitation rather than develop their own original solutions is a mistake in the management process. Blind reproduction of solutions existing elsewhere is one of most serious objections against benchmarking. In fact, the mutual cooperation of parties lies at the core of the idea of benchmarking. Benchmarking is not supposed to be blind reproduction, with perhaps an addition of industrial espionage. It is about 
using the patterns developed by others, but on the basis of mutual cooperation and exchange of opinions in order to learn from each other (Kaszubska, 2012).

Additionally, managers are often convinced that their institutions and fields are so exceptional, that they cannot be meaningfully compared to any other. The pride they take in cultivating their organisation, its uniqueness and its history, is one possible obstacle in acquiring knowledge which could help to improve their performance. It is up to creating body stimulate in such managers a need to refer to external comparisons and additional analyses of their activity.

It also has to be said that many hospitals and creating bodies cling too tightly to dominant approach in healthcare industry. Therefore, they are unable to understand external information and adopt a neutral attitude against new opportunities.

Benchmarking is a management tool commonly used in a competitive market. Although the "healthcare market" does not show the characteristics of competitiveness in full, benchmarking still seems to be a very good tool of quality improvement for the entities of that market. In Poland, benchmarking is applied mostly in production industry, sometimes in services. Criteria and indicators of comparison help in running business, seeking best solutions and strategies of development.

A complex benchmarking tool dedicated for hospitals, especially hospitals founded by public (local) authorities, did not exist in Poland until 2015. Benchmarking tools available on the market were focused on business performance of the hospitals, and they were often mere comparison tools used only for choosing the best clearance option in reports for the National Healthcare Agency (NFZ). Although reduced in its application, it was a practical solution, so managers have come to rely on it. Other benchmarking needs weren't reported. A benchmarking tool with broader spectrum of analysis was prepared, tested and finished, in 2015 as a part of EU-financed project within the scope of Human Capital OP, Priority 5 - Good Governance, realized under the auspices of Ministry of Administration and Digitization, named "Portraits of hospitals - opportunities maps; quality monitoring in public services and benchmarking of governance of hospitals founded by local authorities".

The role of the author of this article was to prepare both the concept of a benchmarking tool for ownership supervision and management of hospitals subordinated to local authorities (including designing it, its logic and functioning) and methodology of benchmarking research (www.portretyszpitali.pl), as well as performing monitoring and professional supervision over the project.

\section{Design brief of a benchmarking tool}

The benchmarking tool named "Portraits of hospitals - maps of opportunities" was conceived for purposes of effective supervision of hospitals founded by local authorities. It is dedicated to:

- local authorities, for the purpose of monitoring the effectiveness of dependant hospitals (their economic results, defining strengths and weaknesses in organization and functioning of the hospital, together with suggestions of improvement),

- hospital management (in a hospital founded by a local authority), for the purpose of improving effectiveness according to the interest of owners.

The tool is complex: hospital benchmarking can be created from various perspectives, as can diagnoses and recommendations of improvement of performance. In particular, it facilitates a systematic up-to-time identification and evaluation of ongoing processes in various perspectives, in order to define areas of the most and the least 
effective stewardship of resources. Thus it can identify good practices in effective business and management, as well as in service quality. These can be then recommended to the founding bodies and managements of hospitals.

The tool can be used in two main areas of activity of hospitals as presented on the Figure 1 . Service quality of a hospital can be analysed and evaluated in reference to every area of its activity.

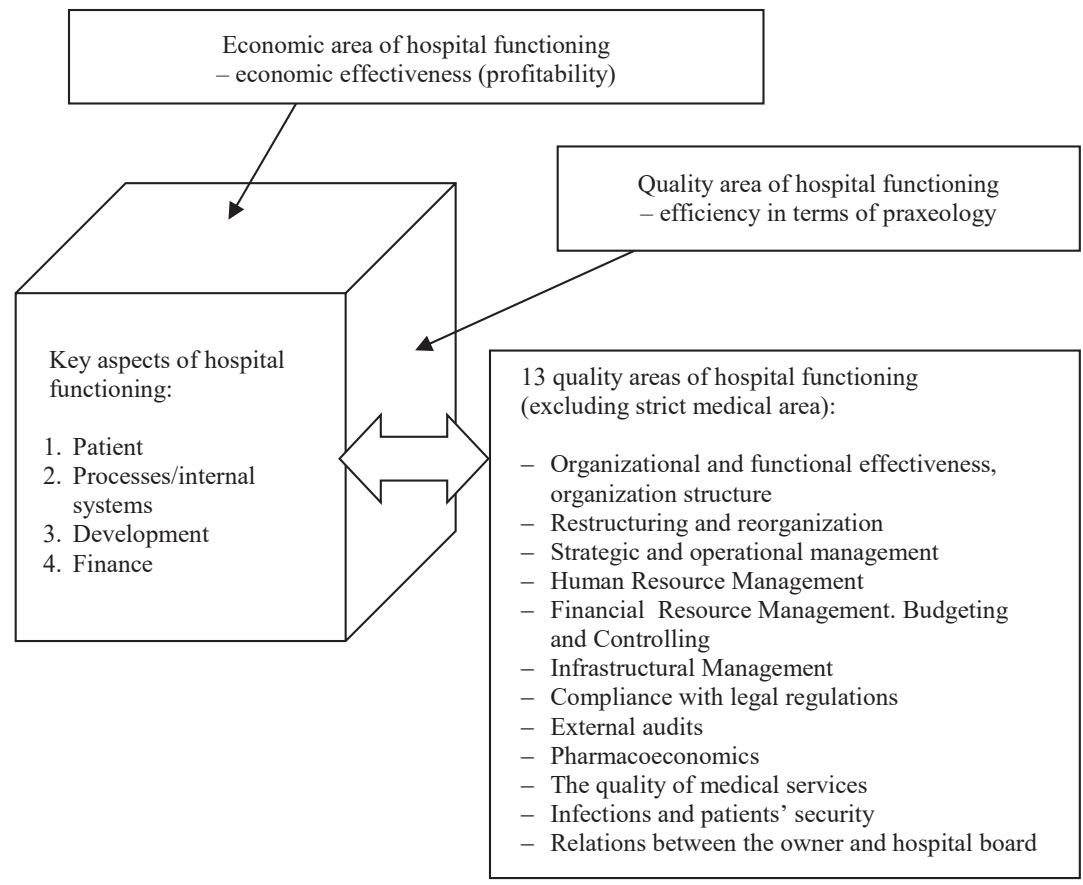

Figure 1. Benchmarked aspects and areas of hospital activity

Source: original research.

The tool is oriented toward rationalisation of hospital management from two different perspectives. From the perspective of a medical entity, rational management of (material, financial, human) resources is an issue. From the point of view of the local authority it is a rational distribution of those resources in local/regional area. Solving the problems on local authority level is impossible without a correct diagnosis of resources management status quo in all dependent entities or stimulating managements to quality and effectiveness improvement. Through its benchmark and recommendation facilities, our instrument provides a solution for both local authorities and hospital managers.

\section{Conclusions}

Local governments need a practical tool for impartial and systematic diagnosing the quality and efficiency of stewardship of hospital's resources, for quality improvement monitoring, proper evaluation and motivation of 
management and, as a result, preventing: waste of public funds, deterioration of working conditions and salaries, and quality of provided services.

"Portraits of hospitals - maps of opportunities" solution combines a benchmarking feature (comparison of hospitals with respect to homogeneous database and internal information) with monitoring conditions, results and improvement of internal economy. Such complex managing instruments weren't available in Poland so far. There were only partial, commercial solutions available, based on several economic or technical efficiency indicators with no inter-hospital benchmarking features in respect to monitoring of effects, and no reference to the causes of efficiency reduction in terms of management quality. The benchmarking tool can combine benchmark (the possibility of comparison within one hospital, and one with another) and efficiency control feature.

The more useful is the benchmarking tool for the management of the hospital, the more useful it is for the supervision by local government, for it gives to the latter more objective data for correct evaluation of a director and for defining the requirements referring to quality and efficiency improvement.

The management has at its disposal the same tool for collecting and sorting out all available knowledge about its organization, for periodical monitoring of conditions, evaluation of improvement in different areas (thus use as a management tool). It is also an objective basis for evaluation of managers' own jobs by a local government.

\section{References}

Hass-Symotiuk, M. (2011). System pomiaru i dokonań szpitala. Warszawa: Wolters Kluwer.

Kaszubska, E. (2012). Benchmarking - nowoczesna metoda planowania strategicznego. Warszawa: PARP.

Nojszewska, E. Mierzenie efektywności szpitali metodą stochastycznej granicznej funkcji kosztów. Warszawa: SGH. Available at: www. szpitale-powiatowe.pl/prez/prez_1.ppsx (2.02.2017).

Porębski, D. (2016). Pomiar efektywności ekonomicznej szpitala z wykorzystaniem zrównoważonej karty wyników [manuscript]. Wrocław: UE we Wrocławiu.

Public Administration Reform Program Report (2000). Efektywne metody zarządzania w administracji publicznej. Warszawa: Instytut Spraw Publicznych.

Rój, J. \& Sobiech, J. (2006). Zarządzanie finansami szpitala. Warszawa: Wolters Kluwer.

www.portretyszpitali.pl.

Cite this article aS: Korenik, D. (2017). Healthcare as a task of local government in Poland. European Journal of Service Management, 21 (1), 11-17. DOI: 10.18276/ejsm.2017.21-02. 